\title{
Response of aquatic macrophyte biomass to limnological changes under water level fluctuation in tropical reservoirs
}

\author{
E. G. Moura Júniora*, A. Pott ${ }^{b}, W$. Severi ${ }^{c}$ and C. S. Zickel ${ }^{d}$

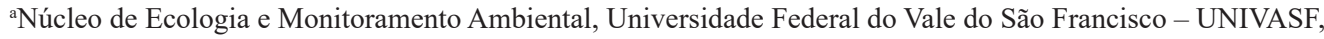 \\ CEP 56300-000, Petrolina, PE, Brasil
}

'Instituto de Biociências, Universidade Federal do Mato Grosso do Sul - UFMS, CEP 79070-900, Campo Grande, MS, Brasil 'Departamento de Pesca e Aquicultura, Universidade Federal Rural de Pernambuco - UFRPE, CEP 52171-900, Recife, PE, Brasil ${ }^{d}$ Departamento de Botânica, Universidade Federal Rural de Pernambuco - UFRPE, CEP 52171-900, Recife, PE, Brasil

*e-mail: mourajunioreg@hotmail.com

Received: May 8, 2017 - Accepted: September 14, 2017 - Distributed: February 28, 2019

(With 2 figures)

\begin{abstract}
We evaluated the response of the biomass of aquatic macrophytes under limnological changes after water level fluctuation (WLF) of two tropical reservoirs (R1 and R2), located in northeastern Brazil. Initially we tested the hypothesis that post-WLF limnological conditions and biomass of macrophytes increase or decrease, depending on the variable or species. We monitored a $4 \times 50 \mathrm{~m}$ permanent plot, in four expeditions per period (pre- or post-WLF), assessing species biomass and 10 limnological variables. We utilized $0.25 \times 0.25 \mathrm{~m}$ quadrats for biomass. Once the effect of WLF in limnological variables and species biomass was confirmed, we utilized Canonical Correspondence Analysis to understand the relationship between limnological variables and species biomass. The abundant and/or dominant species in pre-WLF of R1 (Pistia stratiotes, Eichhornia crassipes and Salvinia auriculata) and R2 (Paspalidium geminatum and $S$. auriculata) reduced their biomass post-WLF and were correlated with temperature, total phosphorous and nitrate. The reduced biomass of $P$. stratiotes, E. crassipes and $S$. auriculata in post-WLF widened resource availability, allowing coexistence of species. Therefore, we suggest that the change of limnological conditions in post-WLF in artificial lakes acts only as a moderator factor of the interspecific interaction (especially coexistence), without direct relation between these conditions and species biomass.
\end{abstract}

Keywords: aquatic plant, limnology, plant ecology.

\section{Resposta da biomassa de macrófitas aquáticas às mudanças limnológicas consequentes da variação do nível da água em reservatórios tropicais}

\begin{abstract}
Resumo
Avaliamos a resposta da biomassa de macrófitas aquáticas às alterações ambientais após flutuação do nível de água (WLF) de dois reservatórios tropicais (R1 e R2), localizados no Nordeste do Brasil. Inicialmente, testamos a hipótese de que após uma WLF as condições limnológicas e a biomassa das macrófitas aumentam ou diminuem, dependendo da variável ou espécie. Por isso, monitoramos uma parcela permanente de $4 \times 50 \mathrm{~m}$, em quatro amostragens por período (pré ou pós-WLF), avaliando a biomassa de espécies e 10 variáveis limnológicas. Utilizamos quadrados de $0,25 \times 0,25 \mathrm{~m}$ na amostragem da biomassa. Uma vez que o efeito do WLF em variáveis limnológicas e biomassa das espécies foi confirmado, utilizamos a Análise de Correspondência Canônica para compreender a relação das variáveis limnológicas com a biomassa de espécies. As espécies abundantes e/ou dominantes no pré-WLF de R1 (Pistia stratiotes, Eichhornia crassipes e Salvinia auriculata) e R2 (Paspalidium geminatum e S. auriculata) reduziram sua biomassa pós-WLF, correlacionando-se diretamente com temperatura, fósforo total e nitrato. A redução da biomassa de $P$. stratiotes, E. crassipes e $S$. auriculata em pós-WLF ampliou a disponibilidade de recursos, permitindo a coexistência de espécies. Portanto, sugerimos que a mudança das condições limnológicas no pós-WLF em lagos artificiais atua apenas como um fator moderador da interação interespecífica (em especial a coexistência), sem relação direta entre essas condições e a biomassa das espécies.
\end{abstract}

Palavras-chave: planta aquática, limnologia, ecologia vegetal. 


\section{Introduction}

The present understanding of the ecology of aquatic ecosystems does not yet allow to delineate structuring of macrophyte communities in environments periodically influenced by water level fluctuations (WLF), such as artificial lakes (Zohary and Ostrovsky, 2011; Cunha-Santino et al., 2016; Moura Júnior et al., 2016). The intensity and duration of a WLF exerts relevant influence on the limnological conditions and on the ecological processes structuring aquatic communities, including the macrophytes (Wetzel, 2001). In general, a WLF causes changes of water volume, temperature, turbidity, electrical conductivity, tranparency and/or nutrients (Esteves and Camargo, 1986; Neiff, 1996; Esteves, 2011).

The studies on the response of biomass of aquatic macrophytes under a WLF show divergent results regarding the species (Byun et al., 2017). Some reports point out that after a WLF of intermediate intensity a reduction of the biomass of aquatic macrophytes occurs, inasmuch as their physiological capacities are exceeded (Paillisson and Marion, 2006; Lacoul and Freedman, 2006; Zohary and Ostrovsky, 2011; Bottino et al., 2013). In contrast, other works evidenced increase for biomass of particular species of macrophytes after WLF in rivers or tropical lakes (Neiff, 1975; Neiff et al., 2001; Menezes et al., 1993; Bini, 1996; Pompêo et al., 2001). Furthermore, there is no consensus upon the predictors of biomass of the macrophyte species under a WLF. Most specialists on aquatic macrophytes believe that the specificities of the water abiotic conditions after WLF determine the capacity of plant biomass production (Lacoul and Freedman, 2006; Henry-Silva et al., 2008; Zohary and Ostrovsky, 2011; Bottino et al., 2013). Some biotic variables such as interespecific competition and coexistence are relevant factors in the structuring of communities (Van Gerven et al., 2015; Moura Júnior et al., 2016) or biomass of aquatic macrophytes (Camargo and Florentino, 2000; Byun et al., 2017) in environment under variation of WLF.

In this context, we proposed a study to investigate the response of the biomass of aquatic macrophyte species after a WLF of intermediate intensity that occurred in two tropical artificial lakes. Initially we evaluated the hypothesis that WLF distinctly influence the biomass of the species of aquatic macrophytes and the limnological conditions. Once the hypothesis was confirmed, we had the following objectives: $\mathrm{i}$ - to understand the relation between the limnological variables and the species biomass in pre- and post-WLF of the reservoirs; and ii - to evaluate the patterns of coexistence for species biomass in post-WLF of the reservoirs.

\section{Material and Methods}

\subsection{Description of the study area and the WLF event}

The reservoirs Tapacurá-R1 (0802'32.1”'S, 35 11'46.5”W) and Cursai - R2 (07 52' 41.6” S, 35 $15^{\circ}$ ' 30.9' W) are located in the hydrographic basin of the Capibaribe River, northeastern Brazil (Figure 1). The R1 had a maximum depth of $108 \mathrm{~m}$ with a surface area of $58 \mathrm{Km}^{2}$ and maximum volume of 155 million $\mathrm{m}^{3}$, while $\mathrm{R} 2$ reached $95 \mathrm{~m}$ deep, area of $58 \mathrm{Km}^{2}$ and volume of 24 million $\mathrm{m}^{3}$ (SRHE, 2015).
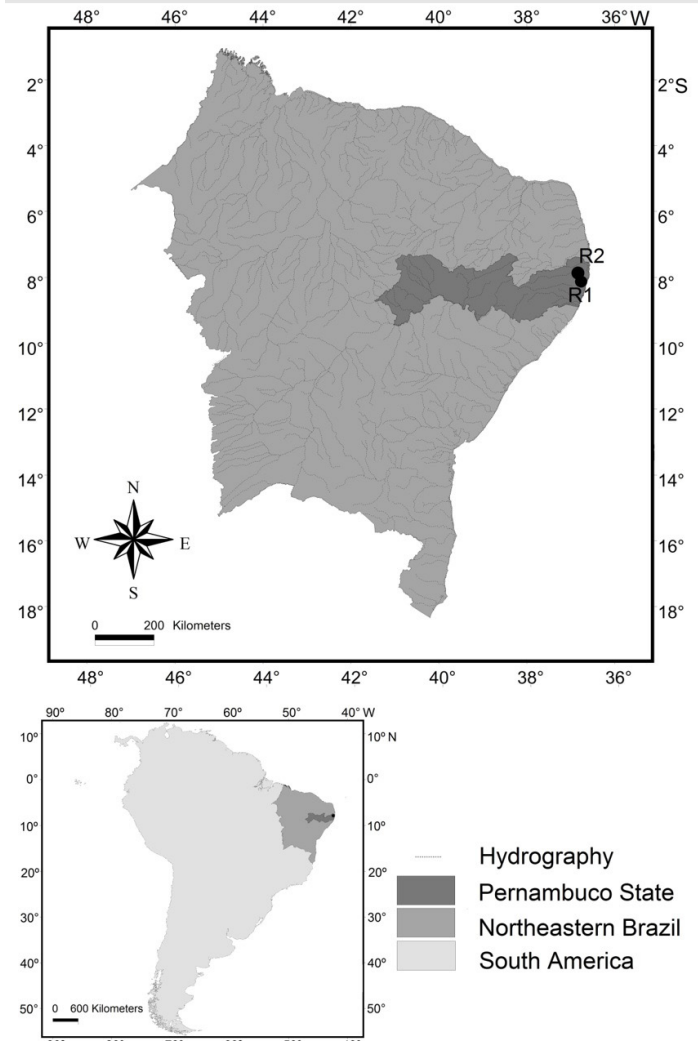

Figure 1. Map of Northeastern Brazil and the geographic location of the Tapacurá (R1) and Cursai (R2) Reservoirs.

The average monthly rainfall in the watershed of the reservoirs varies from $221 \mathrm{~mm}$ to less than $70 \mathrm{~mm}$ (APAC, 2016). In June 2010, the meteorological station of Tapacurá recorded $448 \mathrm{~mm}$ of rain, when $307 \mathrm{~mm}$ fell within only 10 days (APAC, 2016). Such heavy rains caused a WLF of up to $8 \mathrm{~m}$ in the Capibaribe river, being qualified by Moura Júnior et al. (2016) as an intermediate flood event.

\subsection{Sampling period and data collection}

We made eight sampling expeditions to each reservoir: four before water level fluctuation (pre-WLF) and four after (post-WLF). Field work in the pre-WLF period was done in November 2008, and May, August and December 2009, and the post-WLF in August and November 2010, and February and June 2011.

We established a $5 \mathrm{~m} \times 40 \mathrm{~m}$ rectangular permanent plot in each lake. The shortest limits of the plot were perpendicular to the shore and the longest parallel to the shore. The aquatic macrophyte stand where we established the permanent plot of R1 and R2 had mean width of $5 \mathrm{~m}$ in all field expeditions. This way, the permanent plot covered all assemblages of aquatic plant types described by Cook (1996), except amphibious. The criteria to place the permanent plot were the same utilized by Moura Júnior et al. (2016).

At each sampling, the permanent plot was evaluated regarding species biomass and limnological variables. Sampling of the species biomass followed the sampling 
quadrats technique according to Howard-Williams (1975). Within the permanent plot we placed $0.25 \times 0.25$ m quadrats where each species presented cover above $0.0625 \mathrm{~m}^{2}$. We collected one to twelve sampling quadrats per species, depending on the number of their plant groups in the permanent plot. We prioritized sampling in banks of different distances from the shore, so we could capture variations of the species biomass proveniences from the depth gradient. The biomass collected in quadrats of a same species were added together, this sum being made for each sampling period.

The emergent or floating aquatic macrophytes were collected manually or with a $50 \mathrm{~mm}$ mesh net, and the submerged utilizing a $1 \mathrm{~cm}$ mesh immersion net or an iron stick with hooks. The plants collected in each quadrat were identified, kept in labeled plastic bags, and taken to the Laboratory of Floristics of Coastal Ecosystems (LAFLEC) of the Federal Rural University of Pernambuco (UFRPE). The biological material was washed to remove the sediment. We identified the collected material using taxonomic keys available in the literature and morphological comparison with exsiccate deposited in the herbarium Vasconcelos Sobrinho (PEUFR) at UFRPE.

Next, this plant material was put in paper bags and oven dried at $70{ }^{\circ} \mathrm{C}$ until constant weight and ash free. The dry biomass of each species was weighed on digital balance $( \pm 0.001 \mathrm{~g})$, the values being expressed in grams of dry mass per square meter $\left(\mathrm{gDW} / \mathrm{m}^{2}\right)$.

The limnological variables conductivity $-\mathrm{Con}\left(\mu \mathrm{S} . \mathrm{cm}^{-1}\right)$, dissolved oxygen - DO (mg. $\left.\mathrm{L}^{-1}\right), \mathrm{pH}$, temperature Tem $\left({ }^{\circ} \mathrm{C}\right)$ and turbidity - Tur (NTU) were assessed in the field using a multiparameter probe (YSI, model 556 MPS - Multiprobe System), and transparency - Secchi (m) with the Secchi disc. The concentrations of nitrate - $\mathrm{NO}_{3}$ $\left(\mathrm{mg} . \mathrm{L}^{-1}\right)$, nitrite $-\mathrm{NO}_{2}\left(\mathrm{mg} . \mathrm{L}^{-1}\right)$, phosphate $-\mathrm{PO}_{4}\left(\mathrm{mg} . \mathrm{L}^{-1}\right)$ and total phosphorous - TP (mg. $\left.\mathrm{L}^{-1}\right)$ were determined following laboratorial protocols (Golterman et al., 1978; Mackereth et al., 1978; Valderrama, 1981). The water samples for laboratorial analysis and the multiparameter readings were taken in duplicate from the sub-surface $(0.25 \mathrm{~cm}$ deep) in the plot edges. The samples for laboratorial analyses were manually collected, kept in $500 \mathrm{~mL}$ bottles and cooled to avoid oxidizing the nitrogen and phosphate compounds and taken to the Limnology Laboratory of UFRPE.

\subsection{Analyses of data}

Species biomass was treated per sampling period (pre- or post-WLF) and the permanent plot was considered our sampling unit. We assembled two matrices of data: A - matrix of species biomass per expedition and sampling period; B - matrix of the limnological variables per expedition and sampling period. The first matrix included the data of biomass of species present in more than $10 \%$ of samples (Causton, 1988).

We transformed the data of the matrices A and B $(\log \mathrm{x}+1)$ and applied the tests of Shapiro-Wilk and Cochran to evaluate if the data were normal and homoscedastic, respectively, what was confirmed. We elaborated new matrices A and B, now with transformed data. We utilized Analysis of Variance (ANOVA) to evaluate differences in species biomass and limnological variables in pre- or post-WLF.

We applied a forward selection to indicate the explicative limnological variables (Blanchet et al., 2008) of the biomass of macrophytes recorded in the permanent plot of R1 and/or R2, optimizing the matrices A and B with transformed data. Next, we applied Canonical Correspondence Analysis (CCA) to examine the explanatory limnological variables correlated with species biomass. We applied a Monte Carlo permutation test (999 permutations) to verify the significance of the correlations indicated by the final CCA and the number of significant axes of this analysis. The ANOVAs, Shapiro-Wilk, Cochran, forward selection, and CCAs were performed using the software R (R Core, 2013). We utilized the packages "vegan" to compute ANOVA and CCA, beside "forward" to compute a forward selection.

\section{Results}

\subsection{Evaluation of hypotheses}

We detected significant differences of the variables Con, Tur, $\mathrm{PO}_{4}, \mathrm{TP}, \mathrm{DO}$ and $\mathrm{NO}_{3}$ between the periods pre- and post-WLF of R1 and/or R2 (Table 1). We recorded distinct responses in the species biomass in post-WLF (Table 2).

\subsection{Limnological variables and biomass of the species}

The variables Tur and TP presented reduction in Post-WLF of R1 and R2. The concentration of $\mathrm{PO}_{4}$ decreased in Post-WLF of R2, and DO increased in R1 for the same period. Con decreased in Post-WLF of R1 and increased for R2 in the same period (Table 1).

The species Eichhornia crassipes (Mart.) Solms was dominant regarding the total biomass recorded in different sampling periods of R1, and Pistia stratiotes L. and Salvinia auriculata Aubl. were abundant in pre-WLF. These species presented reduction in biomass in post-WLF, while Polygonum ferrugineum Wedd. increased its biomass in the same period. Ceratopteris pteridoides (Hook.) Hieron. was only recorded in pre-WLF, and Hydrocotyle ranunculoides L.f. and Ludwigia helminthorrhiza (Mart.) H. Hara in post-WLF of R1 (Table 2).

In R2, the species Paspalidium geminatum (Forssk.) Stapf and $S$. auriculata were abundant in the distinct sampling periods, while $L$. helminthorrhiza was abundant in post-WLF (Table 2). Eichhornia crassipes, P. geminatum and $S$. auriculata presented reduced biomasses in post-WRL of R2, while L. helminthorrhiza increased its biomass in the same period (Table 2). The species $P$. ferrugineum and $H$. ranunculoides were recorded exclusively in pre-WLF and Oxycaryum cubense (Poepp. \& Kunth) Lye in post-WLF of R2 (Table 2).

\subsection{Limnological variables $\times$ biomass}

According to forward selection only DO, Tem, $\mathrm{NO}_{3}$ and TP were correlated with the macrophytes biomass in R1 and R2. (Table 3). The Monte Carlo test indicated satisfactory performance of the CCA $(p=0.003)$ for both 
Table 1. Means and standard deviations (SD) of the limnological variables assessed in the permanent plot for pre- or post-water level fluctuation (WLF) periods in the Tapacurá and Cursai Reservoirs. Results of ANOVA (t) between means of the limnological variables.

\begin{tabular}{|c|c|c|c|c|}
\hline \multirow{3}{*}{$\begin{array}{c}\text { Variables } \\
\text { (unit of measurement) }\end{array}$} & \multicolumn{2}{|c|}{ Cursai } & \multicolumn{2}{|c|}{ Tapacurá } \\
\hline & Pre-WLF & Post-WLF & Pre-WLF & Post-WLF \\
\hline & Mean \pm SD & Mean \pm SD & Mean \pm SD & Mean \pm SD \\
\hline Conductivity $\left(\mu \mathrm{S} . \mathrm{cm}^{-1}\right)$ & $286 \pm 28.08$ & $310.25 \pm 43.43 * *$ & $458.50 \pm 41.03$ & $423.25 \pm 17.63 * * *$ \\
\hline Dissolved oxygen (mg.L $\left.\mathrm{L}^{-1}\right)$ & $5.55 \pm 0.92$ & $5.88 \pm 0.45$ & $4.05 \pm 1.17$ & $5.77 \pm 1.74^{*}$ \\
\hline Nitrate $\left(\mathrm{mg} . \mathrm{L}^{-1}\right)$ & $1.07 \pm 0.33$ & $1.67 \pm 0.18$ & $1.05 \pm 0.33$ & $0.70 \pm 0.23$ \\
\hline Nitrite (mg.L $\left.L^{-1}\right)$ & $0.78 \pm 0.32$ & $0.26 \pm 0.6$ & $1.15 \pm 0.40$ & $2.20 \pm 1$ \\
\hline Orthophosphate (mg. $\left.\mathrm{L}^{-1}\right)$ & $2.14 \pm 0.04$ & $1.11 \pm 0.08^{*}$ & $2.62 \pm 0.22$ & $2.30 \pm 0.08$ \\
\hline $\mathrm{pH}$ & $7.42 \pm 0.29$ & $7.53 \pm 0.53$ & $7.20 \pm 0.28$ & $7.27 \pm 0.38$ \\
\hline Secchi (m) & $0.55 \pm 0.05$ & $0.72 \pm 0.09$ & $0.40 \pm 0.08$ & $0.52 \pm 0.05$ \\
\hline Temperature $\left({ }^{\circ} \mathrm{C}\right)$ & $28.35 \pm 2.25$ & $28.17 \pm 2.35$ & $28.97 \pm 0.86$ & $28.35 \pm 2.07$ \\
\hline Total phosphorous (mg.L $\mathrm{L}^{-1}$ ) & $2.31 \pm 0.27$ & $1.5 \pm 0.17 *$ & $7.27 \pm 0.05$ & $2.55 \pm 0.12 * * *$ \\
\hline Turbidity (NTU) & $73.22 \pm 23.49$ & $43.5 \pm 23.78 * *$ & $57.67 \pm 3.25$ & $71.42 \pm 4.67 * * *$ \\
\hline
\end{tabular}

$* \mathrm{p}<0.05 ; * * \mathrm{p}<0.001 ; * * * \mathrm{p}<0.0001$

Table 2. Mean and standard deviation (SD) of the total biomass $\left(\mathrm{DW} / \mathrm{m}^{2}\right)$ of the species recorded in the sampling units of the Cursai and Tapacurá reservoirs, during the pre- and post-Water Level Fluctuation (WLF) periods. Results of ANOVA (t) between means of the species biomass.

\begin{tabular}{lccccc}
\hline \multirow{2}{*}{\multicolumn{1}{c}{ Species }} & \multicolumn{2}{c}{ CURSAI } & \multicolumn{2}{c}{ TAPACURÁ } \\
\cline { 2 - 5 } & & Pre-WLF & Post-WLF & Pre-WLF & Post-WLF \\
\cline { 2 - 5 } & Mean \pm SD & Mean \pm SD & Mean \pm SD & Mean \pm SD \\
\hline Pistia stratiotes L. & - & - & $112.4 \pm 9.14$ & $26.4 \pm 16.7^{* *}$ \\
Hydrocotyle ranunculoides L.f. & $1.3 \pm 2.7$ & - & - & $4 \pm 3.4$ \\
Oxycaryum cubense (Poepp. \& Kunth) Lye & - & $14.7 \pm 10.0$ & - & - \\
Ludwigia helminthorrhiza (Mart.) H. Hara & $4.3 \pm 6.3$ & $85.0 \pm 8.5^{* *}$ & - & $4.0 \pm 8.0$ \\
Paspalidium geminatum (Forssk.) Stapf & $249.5 \pm 50.1$ & $94.7 \pm 50.1^{* *}$ & - & - \\
Polygonum ferrugineum Wedd. & $12.7 \pm 14.9$ & - & $0.7 \pm 0.3$ & $4.3 \pm 0.3^{* *}$ \\
Eichhornia crassipes (Mart.) Solms & $19.7 \pm 2.83$ & $2.3 \pm 2.7^{*}$ & $861.3 \pm 63.8$ & $410.7 \pm 38.6^{* *}$ \\
Ceratopteris pteridoides (Hook.) Hieron. & - & - & $1.7 \pm 3.4$ & - \\
Salvinia auriculata Aubl. & $127.0 \pm 28.7$ & $98 \pm 54.1^{*}$ & $65.9 \pm 28.9$ & $31.3 \pm 16.5^{*}$ \\
\hline
\end{tabular}

- species not recorded in the samples; * $\mathrm{p}<0.001 ; * * \mathrm{p}<0.0001$.

Table 3. Forward selection results indicated correlation between abiotic variables and macrophyte biomass in R1 and R2.

\begin{tabular}{lcc}
\hline \multicolumn{1}{c}{ Variable } & $\boldsymbol{p}$ value & $\mathbf{R}^{\mathbf{2}}$ \\
\hline Total phosphorous & $<0.001$ & 40.28 \\
Dissolved oxygen & $<0.001$ & 26.12 \\
Nitrate & 0.010 & 12.64 \\
Temperature & 0.021 & 2.16 \\
Conductivity & 0.059 & 0.21 \\
Inorganic phosphate & 0.072 & 0.18 \\
Nitrite & 0.091 & 0.11 \\
Transparency & 0.102 & 0 \\
Turbidity & 0.190 & 0 \\
pH & 0.211 & 0 \\
Total & $<0.001$ & 81.70 \\
\hline
\end{tabular}

$\mathrm{R}^{2}$ : percentage of explained variance. first axes (Figure 2). The axes 1 or 2 of the CCA expressed relations between the limnological variables selected by the preliminary CCA and the biomass of the abundant species in pre- and post-WLF of R2 (axis 1) or R1 (axis 2).

The CCA did not point clear relations between the biomass of $P$. geminatum and the limnological variables. In R1, the biomass assessed for E. crassipes, P. stratiotes and $S$. auriculata in the sampling units of pre-WLF presented direct correlation with $\mathrm{NO}_{3}$ and Tem and inverse with DO. In contrast, the biomass recorded in post-WLF for O. cubense was inversely correlated with $\mathrm{NO}_{3}$ and Tem and directly with DO (Figure 2). The biomass of $S$. auriculata in pre-WLF of R2 was directly correlated with Tem, TP and $\mathrm{NO}_{3}$ and inversely with $\mathrm{DO}$, while the biomass of L. helminthorrhiza and $O$. cubense in Post-WLF showed inverse relation with Tem, TP and $\mathrm{NO}_{3}$ and direct with DO (Figura 2). 


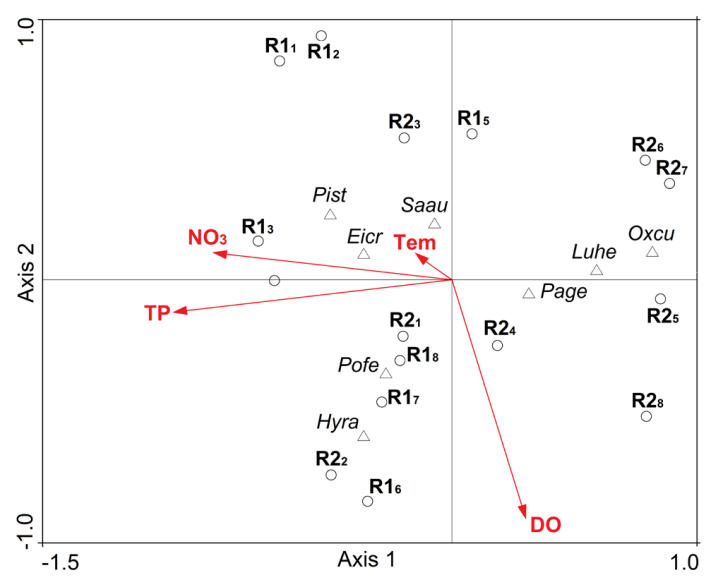

Figure 2. Representation of the Canonical Correspondence Analysis(CCA) according to thebiomass ofaquaticmacrophytes in the sampling units of pre- and post- Water Level Fluctuation (WLF) in the Tapacurá (R1) and Cursai (R2) Reservoirs. $\left({ }_{1,2,3,4}\right)$ - number of sampling units of the R1 and R2 during the pre-WLF; $\left({ }_{5,6,7,8}\right)$ - number of sampling units of the R1 and R2 during the post-WLF; (O) - sampling unit; $(\Delta)$ - macrophyte species; (Pist) - Pistia stratiotes; (Eicr) - Eichhornia crassipes; (Saau) - Salvinia auriculata; (Pofe) - Polygonum ferrugineum; (Hyra) - Hydrocotyle ranunculoides; (Page) - Paspalidium geminatum; (Luhe) - Ludwigia helminthorrhiza;(Oxcu)-Oxycaryumcubense;(Tem)-temperature; $\left(\mathrm{NO}_{3}\right)$ - nitrate; (TP) - total phosphorus; (DO) - dissolved oxygen.

\section{Discussion}

We confirmed the hypothesis that one WLF causes changes in the limnological conditions and species biomass of aquatic macrophytes. Biomass productivity of aquatic macrophytes is related with their capacity to absorb $\mathrm{NO}_{3}$ and/or $\mathrm{PO}_{4}$, transforming them in organic compounds (Camargo et al., 2003; Henry-Silva et al., 2008; Bottino et al., 2013). Species of the genera Pistia, Salvinia or Eichhornia present high stocks of $\mathrm{N}$ or $\mathrm{P}$ in their tissues (Martins et al., 2003; Henry-Silva and Camargo, 2000, 2006), moreover when submitted to an environment of reduced WLF (Neiff et al., 2008; Medeiros et al., 2016). Water temperature is also a variable directly related with the production of aquatic plant organic matter (Bottino et al., 2013). Such information explains the results of biomass of $E$. crassipes, $P$. stratiotes and $S$. auriculata in pre-WLF of R1 or R2, as well as the correlations between species/limnological variables obtained by CCA. We believe that the representatively of $P$. geminatum in the amount of biomass verified in both analyzed periods in R2 has masked its relation with the limnological variables evaluated in the CCA.

However, a WLF of intermediate or large intensity causes loss of structural compounds in aquatic macrophytes, favoring the appearance of debris which cause plant death (Pompêo and Moschini-Carlos, 2003). Aquatic macrophytes rapidly degrade labile or refractory fractions when influenced by WLF in reservoirs (Bianchini Júnior, 1997). Such mentioned inferences were corroborated by the reduction of biomass of $P$. stratiotes, $S$. auriculata and
E. crassipes in Post-WLF of R1 and/or R2, as well as the correlations between species/limnological variables pointed by the CCA.

The inverse relation of Tem, $\mathrm{NO}_{3}$ and/or $\mathrm{PO}_{4}$ with $O$. cubense, L. helminthorrhiza or P. ferrugineum in the CCA called our attention, once these species are adjusted to waters rich in nitrogenate and phosphate nutrients (Mormul et al., 2010; Meyer and Franceschinelli, 2011; Moura Júnior et al., 2011; Tsheboeng et al., 2014; Xavier et al., 2016). It is possible that the limnological variables indicated by the forward selection have indirect relation with the species biomass in Post-WLF. In this case, the limnological changes in post-WLF of R1 and R2 would act as moderators of other factors not evaluated in the CCA, that would have direct relation with the species biomass. We suggest that interspecific interactions (especially coexistence) is one of such factors. Hence, the limnological changes derived from WLF of R1 and R2 would widen the availability of resources for other species in post-WLF, allowing coexistence.

Such inferences are supported by the reduced biomass of $P$. geminatum, $P$. stratiotes, $S$. auriculata and E. crassipes in Post-WLF of R1 or R2, by the exclusive records of $O$. cubense, L. helminthorrhiza in Post-WLF and increased biomass of $P$. ferrugineum in $\mathrm{R} 1$ and $L$. helminthorriza in $\mathrm{R} 2$ in this last period. In a recent study, Moura Júnior et al. (2016) emphasized the direct influence of competition and coexistence between species in structuring the communities of aquatic macrophytes after the same WLF occurred in R2. They proved that the limnological changes derived from this WLF act as indirect factors of the structuring, and concluded that the limnological variables act only as moderator factors of the interspecific interactions in Post-WLF situations. Other works verified the extraordinary capacity of the interspecific interactions between macrophytes to influence the growth of biomass of these plants (Camargo and Florentino, 2000; Byun et al., 2017) or the low relation between physical-chemical variables of the water and structuring of aquatic macrophyte communities in tropical reservoirs (Cunha-Santino et al., 2016).

In synthesis, we observed that the reduction of water temperature and the increased dilution of compounds essential for photosynthesis in post-WLF of R1 and R2 are inversely correlated with the biomass of the weeds P. stratiotes, S. auriculata and E. crassipes in that period. The reduction in their competitive capacity after the limnological changes derived from WLF of R1 and R2 increased the availability of resources for other species, allowing their coexistence. Therefore, we suggest that the change of the limnological conditions in post-WLF in R1 and R2 is a moderator factor of the interspecific interactions, notably coexistence. Yet, further investigations are needed to pinpoint definitive patterns upon biomass of aquatic macrophytes and their environmental predictors in situations of post-WLF. Nonetheless, we believe that the novelty of our study can highlight it as a theoretical mark on ecology of aquatic macrophytes, particularly for environments influenced by WLF from intermediate intensity flood. 


\section{References}

AGÊNCIA PERNAMBUCANA DE ÁGUAS E CLIMA - APAC, 2016 [viewed 10 September 2015]. Sistema de geoinformação hidrometeorológico de Pernambuco [online]. Recife. Available from: http://www.apac.pe.gov.br/sighpe/

BIANCHINI JÚNIOR, I., 1997. The degradation process of organic matter in reservoirs. In: L.P. ROSA and M.A. SANTOS, eds. Hydropower plants and greenhouse gas emissions. Rio de Janeiro: Tecnologia, pp. 1-27.

BINI, L.M., 1996. Influência do pulso de inundação nos valores de fitomassa de três espécies de macrófitas aquáticas na planície de inundação do alto rio Paraná. Arquivos de Biologia e Tecnologia, vol. 39 , no. 3, pp. 715-721.

BLANCHET, F.G., LEGENDRE, P. and BORCARD, D., 2008. Forward selection of explanatory variables. Ecology, vol. 89, no. 9, pp. 2623-2632. http://dx.doi.org/10.1890/07-0986.1. PMid: 18831183

BOTTINO, F., CALIJURI, M.C. and MURPHY, K.J., 2013. Temporal and spatial variation of limnological variables and biomass of different macrophyte species in a Neotropical reservoir (São Paulo - Brazil). Acta Limnologica Brasiliensia, vol. 25, no. 4, pp. 387-397. http://dx.doi.org/10.1590/S2179-975X2013000400004.

BYUN, C., NAM, J.M. and KIM, J.G., 2017. Effects of flooding regime on wetland plant growth and species dominance in a mesocosm experiment. Plant Ecology, vol. 218, no. 5, pp. 517527. http://dx.doi.org/10.1007/s11258-017-0707-0.

CAMARgo, A. and FlORENTINO, E., 2000. Population dynamics and net primary production of the aquatic macrophyte Nymphaea rudgeana C. F. Mey in a lotic environment of the Itanhaém River basin (SP, Brazil). Brazilian Journal of Biology = Revista Brasileira de Biologia, vol. 60, no. 1, pp. 83-92. http:// dx.doi.org/10.1590/S0034-71082000000100011. PMid:10838927.

CAMARGO, A.F.M., PEZZATO, M.M. and HENRY-SILVA, G.G., 2003. Fatores limitantes ao crescimento de macrófitas aquáticas. In: S.M. THOMAZ and L.M. BINI, eds. Ecologia e manejo de macrófitas aquáticas. Maringá: Eduem, pp. 59-84.

CAUSTON, D.R., 1988. An introduction to vegetation analysis, principles and interpretation. London: Unwin Hyman, 342 p.

COOK, C.D.K., 1996. Aquatic plant book. Amsterdam: SPB Academic Publishing, 228 p.

CUNHA-SANTINO, M.B., FUSHITA, A.T., PERET, A.C. and BIANCHINI-JUNIOR, I., 2016. Morphometry and retention time as forcing functions to establishment and maintenance of aquatic macrophytes in a tropical reservoir. Brazilian Journal of Biology $=$ Revista Brasileira de Biologia, vol. 76, no. 3, pp. 673-685. http://dx.doi.org/10.1590/1519-6984.24214. PMid:27143068.

ESTEVES, F.A., 2011. Fundamentos da Limnologia. 3. ed. Rio de Janeiro: Interciência, 826 p.

ESTEVES, F.A. and CAMARGO, A.F.M., 1986. Sobre o papel das macrófitas aquáticas na estocagem e ciclagem de nutrientes. Acta Limnologica Brasiliensia, vol. 1, no. 1, pp. 273-298.

GOLTERMAN, H.L., CLYMO, R.S. and OHNSTAD, M.A.M., 1978. Methods for physical and chemical analisys of freshwater. Oxford: Blackwell Scientific Publications, 214 p.

HENRY-SILVA, G.G. and CAMARGO, A.F.M., 2000. Composição química de quatro espécies de macrófitas aquáticas e possibilidade de uso de suas biomassas. Naturalia, vol. 25, no. 1, pp. 111-125.
HENRY-SILVA, G.G. and CAMARGO, A.F.M.A., 2006. Chemical composition of floating aquatic macrophytes used to treat aquaculture wastewater. Planta Daninha, vol. 24, no. 1, pp. 21-28. http://dx.doi.org/10.1590/S0100-83582006000100003.

HENRY-SILVA, G.G., CAMARGO, A.F.M. and PEZZATO, M.M., 2008. Growth of free-floating aquatic macrophytes in different concentrations of nutrients. Hydrobiologia, vol. 610, no. 1, pp. 153-160. http://dx.doi.org/10.1007/s10750-008-9430-0.

HOWARD-WILLIAMS, C., 1975. Seasonal and spatial changes in the composition of the aquatic and semiaquatic vegetation of lake Chilwa, Malawi. Vegetation, vol. 30, no. 1, pp. 33-39. http:// dx.doi.org/10.1007/BF02387875.

LACOUL, P. and FREEDMAN, B., 2006. Environmental influences on aquatic plants in freshwater ecosystems. Environmental Reviews, vol. 14, no. 2, pp. 89-136. http://dx.doi.org/10.1139/a06-001.

MACKERETH, J.F.H., HERON, J. and TALLING, J.F., 1978. Water analysis: some revised methods for limnologists. Ambleside: Freshwater Biological Association, 121 p. vol. 36, no. 1.

MARTINS, D., COSTA, N.V., TERRA, M.A., MARCHI, S.R. and VELINI, E.D., 2003. Caracterização química das plantas aquáticas coletadas no reservatório de Salto Grande (AmericanaSP). Planta Daninha, vol. 21, pp. 21-25. http://dx.doi.org/10.1590/ S0100-83582003000400004.

MEDEIROS, J.C.C., COELHO, F.F. and TEIXEIRA, E., 2016. Biomass allocation and nutrients balance related to the concentration of Nitrogen and Phosphorus in Salvinia auriculata (Salviniaceae). Brazilian Journal of Biology $=$ Revista Brasileira de Biologia, vol. 76, no. 2, pp. 461-468. http://dx.doi.org/10.1590/15196984.21114. PMid:26959946.

MENEZES, C.F.S., ESTEVES, F.A. and ANESIO, A.M., 1993. Influência da variação artificial do nível d'água da represa do Lobo (SP) sobre a biomassa e produtividade de Nymphoides indica (L.) O. Kuntze e Pontederia cordata L. Acta Limnologica Brasiliensia, vol. 6, no. 1, pp. 163-172.

MEYER, S.T. and FRANCESCHINELLI, E.V., 2011. Influência de variáveis limnológicas sobre a comunidade das macrófitas aquáticas em rios e lagoas da Cadeia do Espinhaço, Minas Gerais, Brasil. Rodriguésia, vol. 62, no. 4, pp. 743-758. http://dx.doi. org/10.1590/S2175-78602011000400004.

MORMUL, R.P., FERREIRA, F.A., MICHELAN, T.S., CARVALHO, P., SILVEIRA, M.J. and THOMAZ, S.M., 2010. Aquatic macrophytes in the large, sub-tropical Itaipu Reservoir. Revista de Biología Tropical, vol. 58, no. 4, pp. 1437-1451. PMid:21246998.

MOURA JÚNIOR, E.G., ABREU, M.C., SEVERI, W. and LIRA, G.A.S.T., 2011. O gradiente rio-barragem do reservatório de Sobradinho afeta a composição florística, riqueza e formas biológicas das macrófitas aquáticas? Rodriguésia, vol. 62, no. 4, pp. 731-742. http://dx.doi.org/10.1590/S2175-78602011000400003.

MOURA JÚNIOR, E.G., POTT, A., SEVERI, W. and ZICKEL, C.S., 2016. Water level rise induced limnological changes indirectly influencing the structure of aquatic macrophyte communities in a tropical reservoir. Journal of Plant Sciences, vol. 4, no. 6, pp. 195-201.

NEIFF, J.J., 1975. Fluctuaciones anuales en la composition fitocenotica y biomassa de la hidrofitia en lagunas isleñas del Paraná Medio. Ecosur, vol. 2, no. 4, pp. 153-183. 
NEIFF, J.J., 1996. Large rivers of South America: toward the new approach. Verhandlungen des Internationalen Verein Limnologie, vol. 26, no. 1, pp. 167-181.

NEIFF, J.J., CASCO, S.L. and POI DE NEIFF, A., 2008. Response of Eichhornia crassipes (Pontederiaceae) to water level fluctuations in two lakes with different connectivity in the Paraná River floodplain. Revista de Biología Tropical, vol. 56, no. 2, pp. 613-623. PMid:19256432.

NEIFF, J.J., POI DE NEIFF, A.S.G. and CASCO, Y.S., 2001. The effect of prolonged floods on Eichhornia crassipes growth in Paraná River floodplain lakes. Acta Limnologica Brasiliensia, vol. 3 , no. 1, pp. 51-60.

PAILLISSON, J.M. and MARION, L., 2006. Can small water level fluctuations affect the biomass of Nymphaea alba in large lakes? Aquatic Botany, vol. 84, no. 3, pp. 259-266. http://dx.doi. org/10.1016/j.aquabot.2005.10.004.

POMPÊO, M.L.M. and MOSCHINI-CARLOS, V., 2003. Macrófitas aquáticas e perifiton: aspectos ecológicos e metodológicos. São Carlos: RiMa, 124 p.

POMPÊO, M.L.M., HENRY, R. and MOSCHINI-CARLOS, V., 2001. The water level influence on biomass of Echinochloa polystachya (Poaceae) in the Jurumirim reservoir (Sao Paulo, Brazil). Brazilian Journal of Biology $=$ Revista Brasileira de Biologia, vol. 61, no. 1, pp. 19-26. http://dx.doi.org/10.1590/ S0034-71082001000100004. PMid:11340458.

R DEVELOPMENT CORE TEAM - R CORE, 2013 [viewed 10 September 2015]. R: a language and environment for statistical computing [software]. Vienna: R Foundation for Statistical Computing. Available from: http://www.R-project.org/

SECRETARIA PERNAMBUCANA DE RECURSOS HIDRICOS E ENERGÉTICOS - SRHE, 2015 [viewed 10 September
2015]. Ficha técnica e acumulação de água dos reservatórios de Pernambuco [online]. Recife. Available from: http://www. srhe.pe.gov.br/index.php?option=com_content\&view $=$ article \& id=59:monitreserv

TSHEBOENG, G., BONYONGO, M. and MURRAY-HUDSON, M., 2014. Flood variation and soil nutrient content in floodplain vegetation communities in the Okavango Delta. South African Journal of Science, vol. 110, no. 3/4, pp. 1-5. http://dx.doi. org/10.1590/sajs.2014/20130168.

VALDERRAMA, G.C., 1981. The simultaneous analysis of total nitrogen and total phosphorus in natural waters. Marine Chemistry, vol. 10, no. 2, pp. 109-122. http://dx.doi.org/10.1016/03044203(81)90027-X.

VAN GERVEN, L.P.A., DE-KLEIN, J.J.M., GERLA, D.J., KOOI, B.W., KUIPER, J.J. and MOOIJ, W.M., 2015. Competition for light and nutrients in layered communities of aquatic plants. American Naturalist, vol. 186, no. 1, pp. 72-83. http://dx.doi. org/10.1086/681620. PMid:26098340.

WETZEL, R.G., 2001. Limnology: lakes and river ecosystems. San Diego: Academics Press, 679 p.

XAVIER, L.R.C.C., SCHERNER, F., BURGOS, D.C., BARRETO, R.C. and PEREIRA, S.M.B., 2016. Urbanization effects on the composition and structure of macrophytes communities in a lotic ecosystem of Pernambuco State, Brazil. Brazilian Journal of Biology $=$ Revista Brasileira de Biologia, vol. 76, no. 4, pp. 888897. http://dx.doi.org/10.1590/1519-6984.03515. PMid:27224730.

ZOHARY, T. and OSTROVSKY, I., 2011. Ecological impacts of excessive water level fluctuations in stratified freshwater lakes. Inland Waters, vol. 1, no. 1, pp. 47-59. http://dx.doi.org/10.5268/ IW-1.1.406. 